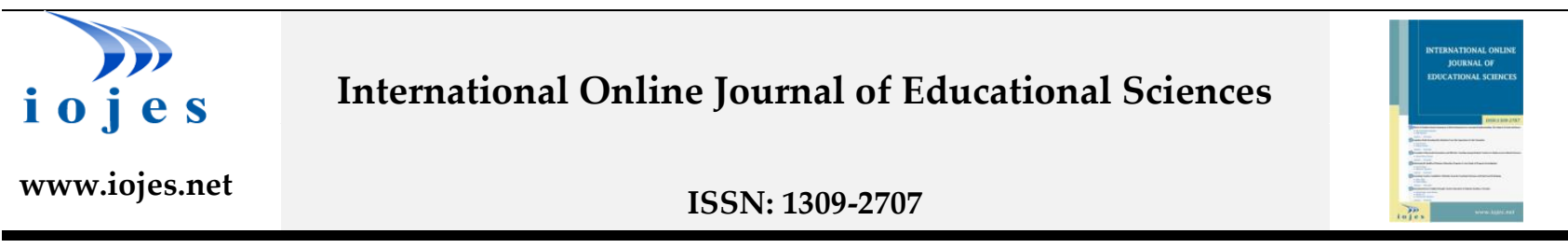

\title{
The Effect of Universal Design for Learning on Metacognitive Awareness and Self -Efficacy Beliefs in English*
}

\section{Research Article}

\section{Nuriye BATMAZ DERER ${ }^{1}$, Yemliha COSKUN²}

${ }^{1}$ Anadolu University, Faculty of Education, Department of Educational Sciences, Eskisehir, Turkey, ORCID: 0000-0003-4279-9159

${ }^{2}$ Sutcu Imam University, Faculty of Education, Department of Educational Sciences, Kahramanmaras, Turkey, ORCID: 0000-0003-2231-3676

To cite this article: Batmaz-Derer, N., \& Coskun, Y. (2021). The effect of universal design for learning on metacognitive awareness and self -efficacy beliefs in English, International Online Journal of Educational Sciences, 13(1), 271-289.

\begin{tabular}{|c|c|}
\hline ARTICLE INFO & ABSTRACT \\
\hline Article History: & $\begin{array}{l}\text { The main aim of this study is to investigate the effectiveness of Universal Design for learning on } \\
\text { students' metacognitive awareness and beliefs of self-efficacy in English of eighth grade }\end{array}$ \\
\hline Received: 19.10 .2020 & $\begin{array}{l}\text { secondary school students. In the research the mixed method, in which both quantitative and } \\
\text { qualitative data are used, was preferred and semi experimental design with pre-test/post-test }\end{array}$ \\
\hline Available online: & design was applied. In the study, eighth grade students in Elbistan/Kahramanmaraş constitute \\
\hline 25.01.2021 & the study group. The research was applied in two groups, one of which is experimental group \\
\hline & and the other one is control group. The experimental group consists of 268 th grade students and \\
\hline & the control group consists of $268 \mathrm{~h}$ grade students. While lessons were taught based on Universal \\
\hline & Design for Learning in experimental group, in control group, lessons were taught according to \\
\hline & the suggested methods of English lesson curriculum. At the end of the study, it was concluded \\
\hline & that metacognitive awareness and self-efficacy beliefs in English of the experimental group \\
\hline & $\begin{array}{l}\text { students, who were applied Universal Design for learning, increased within groups and between } \\
\text { groups. }\end{array}$ \\
\hline
\end{tabular}

(C) 2021 IOJES. All rights reserved

Keywords:

Universal Design for Learning, Metacognitive Awareness, Self-Efficacy belief in English

\section{Introduction}

In today's world, the intensity and inevitability of relations in many inter-societies require mutual communication between people, which we can call global interaction. This phenomenon causes societies with different mother languages to use some foreign languages as a common language of communication.

\footnotetext{
* This study was derived from Nuriye BATMAZ DERER's master's thesis prepared under the supervision of Dr. Yemliha COŞKUN and presented at International Congress on Curriculum and Instruction (ICCI-EPOK 2019).

${ }^{1}$ Corresponding author's address: Anadolu Üniversitesi

Telephone: +905055587634

e-mail: nurderer@windowslive.com

DOI: https://doi.org/10.15345/iojes.2021.01.018
} 
Depending on this situation, it is seen that there is a purposeful effort in the education systems of the societies. Societies try to teach languages commonly used in the world to individuals within the formal and non-formal education system. In this sense, Turkey is seen as too focused on English, depending on the importance of learning foreign languages.

Accepted as a global language, English plays an important role as an inter-communal communication channel (Kannan, 2009). However, it is observed that those trying to learn English as a second language have difficulties in countries where English is not a native language. Because they cannot use English in real life situations and they have to learn sentences in textbooks that are not in a real environment. Therefore, teachers always need to seek useful strategies to reduce the difficulties in teaching the English language (Chen, 2007; Long, 1969; Nunn, 2011). In this sense, one of the important points to be considered is individual differences in learning. Because, one of the problems faced by teachers is the situation regarding how to meet the learning needs of students who learn in different types. Today, although teachers are trained in dealing with differences, many still find it difficult to meet the diverse needs of students in comprehensive classrooms (Meyer \& Rose, 2000). Because teachers plan the course content according to most of the students. However, in order to make the course accessible to students with different learning characteristics, they need to create an individualized learning environment that allows these students to fully participate in the activities and understand the content, considering what they need (Edyburn, 2010).

One of the solutions proposed in recent years to meet the needs of students with different learning styles is Universal Design for Learning. Universal Design for Learning was developed by the Applied Special Technology Center as a lesson planning method that helps teachers prepare effective lessons for different students in their classrooms. The roots of the model are based on the Universal Design (UD) concept developed by the architect Ronald Mace, the founder of the Universal Design center at North Carolina State University (Edyburn, 2010) to the greatest possible extent regardless of age, ability or life situation. It is defined as the design and built environment of all products that can be used by everyone (CAST, 2017). In this sense, Universal Design for Learning (UDL), which includes the proactive application of teaching technology (KingSears, 2009) to create an accessible and interesting teaching activity for students, provides the necessary flexibility and accessibility to reduce barriers for students with different intelligence types (CAST, 2017; Edyburn , 2010) creates opportunities for these students to be included in the lesson by offering curriculums and teaching activities that allow various expressions and adjustments (King-Sears, 2009). Just as the purpose of Universal Design is to remove the obstacles arising from the physical environment and the obstacles arising from the learning environment. In recent years, the teaching philosophy based on Universal Design for Learning was discussed in the field of education. Elementary school teachers and university professors accept Universal Design for Learning as the conceptual and philosophical foundations for creating a teaching and learning model that guides the creation of inclusive, fair and accessible course materials (Schelly, Davies \& Spooner, 2011).

Universal Design for Learning (UDL) is a general educational framework that can be used to meet the needs of students who learn differently in classrooms. This framework prompts educators to rethink curriculum design by exploring the three basic principles of UDL, including multiple means of representation, multiple action and expression tools, and multiple interaction tools. Multimodal representation means multimodal teaching based on a mix of mediums (lectures, video, group discussions) for the transition of concepts (Izzo, Murray \& Novak, 2008). According to this principle, which emphasizes that students should be presented with information and various ways of acquiring knowledge, for example, at the secondary school level, short video clips related to a story or content can be shown. Multiple action and expression principles offer students alternatives to show what they know (Abell, Jung \& Taylor, 2011). It allows students to demonstrate their learning through multiple assessment opportunities. Multimedia projects instead of written 
documents or quizzes and projects instead of a final exam can be given as examples. More than one interaction tool, on the other hand, means that students find the opportunity to interact and learn with content by maximizing students' learning through motivation and interest (Izzo et al., 2008). This method allows the teaching content to be changed or adjusted by the students themselves to meet their learning style, needs or difficulties (Izzo et al., 2008). However, it should be kept in mind that Universal Design for Learning is neither a specific curriculum nor a step-by-step guide for including students of different types. Rather, it is a set of principles covering the design and implementation of courses so that all students can access the curriculum in the way that best suits their abilities and interests. This is seen as a plan for curriculum development based on providing equal opportunities for all students to learn.

Within this plan, Universal Design for Learning has the potential to benefit all students in a classroom, and when implemented, there are many steps from the design of a lesson to the beginning (Rose \& Meyer, 2002) and the prepared curriculum allows teachers to remove potential obstacles that could prevent students from reaching the goal. Therefore, the aim of curriculum based on universal design is not only to help students gain certain knowledge or a certain skill, but also to help them learn to learn on their own (UDL, 2017). However, this is a phenomenon related to the metacognitive awareness level where individuals can control their cognitive processes as well as the belief that individuals can learn to learn, expressed as self-efficacy. Metacognitive awareness (Sonowal and Kalita, 2017), which expresses high-level thinking that includes active control over cognitive processes related to learning, consists of both cognitive knowledge and metacognitive regulation (Flavell, 1979). The development of meta-cognitive knowledge starts from kindergarten and continues throughout the educational process beyond adolescence (Artelt \& Schneider, 2015). Metacognitive awareness is students' knowledge of learning processes, content knowledge, and their own strategies (Wilson, 1999). Students who know what they know and what they do not know, who understand what they do not understand, and who know why they do not understand, have cognitive awareness. Being aware of metacognitive information allows students to plan, monitor and organize their own learning (Schraw \& Dennison, 1994). Learners who know cognition can modify, adapt, and apply what they learn to new tasks and different situations, so that they are more strategic and outperform unwitting learners (Garner \& Alexander, 1989; Pressley \& Ghatala, 1990, Rowe, 1988). Studies show that metacognitive awareness is an important element that guides the learning process (Sáiz Manzanares \& Carbonero Martín, 2017). Many studies have revealed that metacognitive awareness is an important factor in students' academic success (Zhao\&Mo, 2016). However, the ability of the individual to use his / her metacognitive skills is also an important factor here (Tunca\&Alkın-Şahin, 2014). Because individuals show great differences in their metacognitive skills (Molenberghs Trautwein, Böckler, Singer, Kanske, 2016), and while the metacognitive awareness of most of them improves over time, some of them do not (Altındağ\&Senemoğlu, 2013). With cognitive awareness, which can be developed using different strategies in the learning environment and is considered as a teachable situation (Schraw, 1998; Yıldız \& Akdağ, 2017), students learn to think about their own thinking processes and can apply learning strategies that will enable them to overcome difficult learning (Altındağ \& Senemoğlu, 2013). In this sense, teachers can contribute to the development of this awareness by informing them about effective strategies (Paris \& Winograd, 1990) as well as constantly encouraging children to continue planning and monitoring their activities (Brown, 1987).

When we look at the explanations about the concept of metacognitive awareness, we can say that individual effort, that is, developing and implementing different strategies on their own, is prioritized. In this sense, it is possible to say that self-efficacy belief, which expresses the judgment individuals develop about themselves depending on their abilities, is an important factor in the effort to be made. The concept of selfefficacy is a concept first proposed by Bandura and developed within the framework of social cognitive theory (Keskin \& Orgun, 2006; Ekici, 2012). Self-efficacy is expressed as the opinions that people have about their abilities in order to reveal their achievements at a certain level that have an effect on the events that affect their 
lives (Bandura, 1994). Luszczynska, Gutierrez, and Schwarzer (2005) defined the concept of self-efficacy as the belief of the individual in his / her own competencies in fulfilling difficult and unknown responsibilities and struggling with difficulties. The stronger the sense of self-efficacy, which requires people's experiences based on observation, together with their previous experiences (successful or unsuccessful), the more effort they make, and as a result, the rate of achieving the action they want to perform (Bandura, 1997). If a person does not have the belief that he / she can achieve the desired result in a situation, it would not make much sense to expect them to take action or to be persistent when they encounter problems. In this sense, it is seen that people with high self-efficacy take action willingly, are more resistant to problems and achieve successful results, while those with low self-efficacy beliefs do not want to act, give up immediately in the face of difficulties and show low performance due to stress and are doomed to failure. have been observed (Pajares \&Urdan, 2002). However, Bandura (1982) also stated that the expected result with self-efficacy perceptions may not always be compatible with each other, and emphasized that no matter how high self-efficacy is perceived, the expected result of people may be negative, as well as the expected result of people with low self-efficacy may be positive. Definitions and explanations show that self-efficacy belief is considered as an important factor in individuals' efforts and success. In this sense, it is possible to talk about the positive effect of self-efficacy belief in educational activities and academic achievement of students. For example, Mills, Pajares and Herron (2007) found self-efficacy as a strong predictor of language learning success among university students in their study. At the same time, Zimmerman (2000) drew attention to the effect of self-efficacy on learning, arguing that selfefficacy beliefs affect motivation, especially learners' retention and effort spent on learning.

Considering the necessity of metacognitive awareness and self-efficacy belief in terms of Universal Design for Learning, it is seen that it emphasizes that students should be prepared for the course not only academically but also academically and motivationally. It emphasizes that both self-efficacy belief and having metacognitive awareness are particularly important in motivation (UDL, 2017). In other words, according to the Universal Design for Learning, the student should know the best method he/she learns, choose and act accordingly. The ability to do this requires the student to have self-efficacy belief and metacognitive awareness first. Because in this teaching method, each student has to make choices about how to achieve personal goals with the contribution of the teacher, and it is tried to make the student understand how he/she learns (CAST, 2017). Within the framework of all these evaluations, it is thought that it is beneficial to consider the teaching model based on Universal Design for Learning, which can be considered as a different method in terms of education, especially in foreign language teaching in the context of awareness beyond cognition and selfefficacy belief. Considering that one of the reasons why students cannot learn a foreign language, perhaps most importantly, is the lack of motivation that individuals have (Sunel, 1989), instead of teaching a foreign language with a single teaching method in order to increase students' desire and motivation for foreign language lessons, their preference against different teaching methods considering that their motivations may also be different, adapting the foreign language teaching method accordingly will make foreign language teaching more efficient (Kabadayl, 2003). In this sense, the main aim of this study is to investigate the effectiveness of Universal Design for learning on secondary school eighth-grade students' metacognitive awareness and beliefs of self-efficacy in English. Within the scope of this general purpose, the following questions were sought:

1. Is there a significant difference between the English lesson metacognitive awareness posttest scores of the experimental group in which Universal Design for Learning approach was applied and the control group who was taught according to the methods in the English course curriculum?

2. Is there a significant difference between the English course self-efficacy belief posttest scores of the experimental group in which Universal Design for Learning approach was applied and the control group who was taught according to the methods in the English course curriculum? 
3. Is there a significant relationship between metacognitive awareness scores and English self-efficacy belief scores of secondary school eighth-grade students in which Universal Design for Learning was applied?

4. Does the education of secondary school eighth-grade students based on Universal Design for Learning for Learning affect;
a. Contribute to their learning,
b. Their interest in the course,
c. Their active participation in the course? and
d. What are their thoughts about achieving in English lessons?

5. What are the behaviors of the students in the English lesson where Universal Design for Learning was applied?

\section{Methodology}

In this study, mixed method, in which both quantitative and qualitative data are used together, was used. The mixed method is expressed as a research method that includes the processes of collecting and analyzing qualitative and quantitative data together or sequentially in the researcher's study and gathering the collected information (Creswell, Plano Clark, Gutmann \& Hanson, 2003). In mixed methods, qualitative and quantitative approaches are used together in different ways. While sometimes quantitative methods gain weight, sometimes qualitative methods can come to the fore. In some mixed method studies, both methods can be found in equal weight. In this study, embedded (interlocking) pattern, one of the mixed method designs, was used. According to this pattern, one of the qualitative or quantitative methods is more prominent than the other (Yıldırım \& Şimşek, 2013). In this study, metacognitive awareness inventory and English selfefficacy belief scales were used as basic data collection tools, and observation and interview methods from qualitative research approaches were used to obtain detailed and in-depth information about the survey data. The quantitative dimension of the study was based on a quasi-experimental model, and a pretest-posttest control group design. Experimental models are research models in which data are produced under the control of the researcher in order to reveal the cause-effect relationship (Karasar, 2016). In the qualitative dimension, semi-structured interviews and unstructured observation were used. The experimental design related to the research can be seen in Table 1.

Table 1. Pretest-Posttest Experimental Design with Control Group

\begin{tabular}{lccc}
\hline Groups & Pretest & Experimental Process & Posttest \\
\hline Experimental Group & PRT1 & $X$ & PT1 \\
\cline { 2 - 4 } Control Group & PRT2 & & PT2 \\
\hline
\end{tabular}

PRT1: Pre-test measurements applied to the experimental group

PRT2: Pre-test measurements applied to the control group

PT1: Posttest measurements applied to the experimental group

PT2: Posttest measurements applied to the control group

X: Universal Design for Learning

In line with the purpose of the study, two classes, one of which is experimental and the other is control group, were determined. Before starting the study, the metacognitive awareness inventory and the foreign language self-efficacy scale were applied as pretests to both groups. The experimental application part of the 
research took a total of twenty one weeks. Since the English lesson is included in the program as 4 hours a week, the application was carried out within a total of 84 lesson hours. At the end of the experimental process, metacognitive awareness inventory and English self-efficacy belief scale were applied again as posttests. In addition, observations were made by the researcher during the experimental process in order to obtain the data regarding the qualitative dimension of the research, and the students' opinions were taken about the effect of teaching based on universal design.

\section{Study Group}

The eighth-grade students in Elbistan/Kahramanmaraş constitute the study group. In the study, "easily accessible case sampling", one of the sample types, was used to form the experimental and control groups. This sampling method brings speed and practicality to the research. Because in this method, the researcher chooses a situation that is close and easy to access (Yıldırım \& Şimşek, 2013). For the application part of the study, one of the 8 th grades was chosen as the experimental group and the other as the control group. There was a total of 52 students, 26 in the experimental group and 26 in the control group. Lessons were taught with the same teacher in the experimental and control groups.

Before the study was applied, "Metacognitive Awareness Inventory" and "English Self-Efficacy Scale" were applied to students studying in 8-E-F-G-H classes to determine the equivalence of the experimental and control groups. Two identical groups were selected among these four branches. Independent groups t-test was applied to determine whether there was a significant difference between the groups. The applied t-test results are shown in Tables 2 and 3.

Table 2. T-Test Results for the Experimental and Control Groups' Metacognitive Awareness Pretest Scores

\begin{tabular}{lcccccc}
\hline & $\mathbf{n}$ & $\overline{\mathbf{X}}$ & $\mathbf{S}$ & $\mathbf{S d}$ & $\mathbf{t}$ & $\mathbf{p}$ \\
\hline Experimental Group & 26 & 131.23 & 27.27 & \multirow{2}{*}{50} & \multirow{2}{*}{519} & .606 \\
Control Group & 26 & 136.11 & 39.46 & & & \\
\hline
\end{tabular}

When the data in Table 2 were examined, there was no significant difference between the experimental and control group students' metacognitive awareness pretest scores [ $t(50)=.519 ; p>.05]$. When the arithmetic averages of the groups are examined, the mean pre-test metacognitive awareness scores of the control group students are $X=136.11$, while the pre-test metacognitive awareness scores of the experimental group students are $X=131.23$. This finding can be interpreted as the groups are equivalent to each other in terms of metacognitive awareness pretest scores of the groups.

Table 3. T-Test Results for the Experimental and Control Groups' English Self-Efficacy Beliefs Pretest Scores

\begin{tabular}{llrcccc}
\hline & $\mathbf{n}$ & $\overline{\mathbf{X}}$ & $\mathbf{S}$ & $\mathbf{S d}$ & $\mathbf{t}$ & $\mathbf{p}$ \\
\hline Experimental Group & 26 & 83.73 & 17.09 & & & \\
Control Group & 26 & 79.30 & 20.94 & & .834 & .408 \\
\hline
\end{tabular}

When the data in Table 3 were examined, there was no significant difference between the experimental and control group students' score averages regarding English self-efficacy belief pre-test scores $[t(50)=.834$; $\mathrm{p}>$.05]. When the arithmetic averages of the groups are examined, the average scores of the control group students regarding their pre-test English self-efficacy beliefs is $X=79.3$, while the pre-test English self-efficacy belief scores of the experimental group students are $X=83.73$. This finding can be interpreted as that the groups are equivalent to each other in terms of English self-efficacy pre-test scores. 


\section{Process}

In the experimental group, English lessons were taught 26 students of the eighth grade with "Cooking, Communication, Internet, Adventures, Tourism, Chores" units. Lessons were taught from four hours a week to twenty-one weeks in the experimental group, and the lessons were carried out by the researcher. The principles of the teaching approach based on universal design were taken as a basis in the planning and teaching of the lessons.

In the first lesson of the study, the researcher introduced herself to the students and stated why this study was conducted and its purposes, it was said that the lessons would be taught according to the teaching based on Universal design for learning, and the basic information about the teaching approach based on Universal design for learning (their interaction with each other would be more, they would be at the center of all processes, etc.) was given.

Before starting the lesson, interviews were made with the students and the aspects they saw themselves as missing and strong sides were noted. During the first weeks of the experimental study, a meeting was held with the parents and the opinions of the students were received. Students with special circumstances were noted. Parent visits for students started the following week. Separate visits were made to each student's home and their home situation, family problems or problems they had experienced in the past years were noted.

Slides or videos about the words prepared at the beginning of each unit are opened from the interactive board and the students were checked whether they have any prior knowledge about what the unit is about or the English words on the board. After scanning their prior knowledge, the students were expected to make predictions about what the unit was. Afterwards, a video was watched with the new pictures prepared by the teacher along with the pronunciation and spelling of the words belonging to the new unit and it was emphasized that if they didn't know the words, they should have taken notes. After all these processes, the teacher opened the presentation containing the pages of the textbook and the listening texts. In order to relate it to real life, they were asked to share the information they found from magazines and newspapers or internet news in a classroom environment with their friends.

It was taken into consideration that each student is different and lesson plans suitable for different student characteristics were applied in each course. For "speaking" activities, which is one of the most important points of language learning, students were asked to prepare various dialogues and present them in the classroom in the form of "role-play". In addition, activities that students with kinesthetic intelligence can use in real life were implemented in the units possible. In addition to the presentations of the textbook, flashcards and posters were also used in each unit for students with visual intelligence. Listening texts in the textbook for students with auditory intelligence were also used with different song activities in order not to progress only from the textbook. In addition, various videos and presentations related to the subject were sent to the students via EBA. In order to reinforce the vocabulary, word puzzles prepared in each unit were used.

Each student was tried to be taken care of individually, parents were visited and their progress was observed at the end of each unit. As soon as any of the students saw low motivation or unwillingness, one-onone interview with the student was taken and the necessary measures were taken. Various activities (cinema, etc.) were also held outside the school with the student in order to give students morale and motivation. In paired or group studies, students were especially free to determine their spouse or group, and leadership qualities were tried to be revealed. In such studies, although very rarely, interventions were made occasionally by the teacher where necessary. Up-to-date methods related to study methods were mentioned, and information about students' own study methods was obtained. Before starting the lesson, various motivational videos were watched in order to increase the desire and motivation. 
The units in the control group were taught by the teacher of the lesson for 21 weeks. In the control group, the lessons were taught by the teacher of the lesson using methods and techniques prescribed by the English lesson curriculum, such as direct instruction, experimentation, and question-answer. The teacher in the control group used the textbook as a source within the scope of the existing eighth grade English course program and taught the lessons according to the objectives in the teacher's guide book.

\section{Data Collection Tools}

As data collection tools in the study, the Metacognitive Awareness Inventory and the English SelfEfficacy Scale, and the observation and interview forms for qualitative data were used.

The Metacognitive Awareness Inventory, developed by Schraw and Dennison (1994), adapted to Turkish by Abacı, Akın \& Çetin (2007), consists of 52 items. It was seen that the internal consistency reliability coefficient of the inventory was .95, and the Cronbach Alpha coefficients recalculated with the pre-test and post-test data collected in this study were also 95 .

The English Self-Efficacy Scale developed by Hancı Yanar and Bümen (2012), which is used to measure students' self-efficacy beliefs in English lessons, consists of 34 items. According to the results of the Cronbach alpha coefficient calculated to determine the reliability of the scale, the value obtained for the whole scale is 0.97. The Cronbach Alpha coefficient of the scale, which was recalculated with the pre-test and post-test data collected in this study, was found as .92 .

In the research, a semi-structured interview form was prepared by the researchers in order to obtain data on the qualitative dimension of the research. Through this form consisting of five questions, the opinions of the students about the positive and negative aspects of Universal Design for Learning and the effect of the lessons conducted with this approach on the metacognitive awareness and self-efficacy beliefs of the students were taken. In order to ensure the content, structure and language validity of the interview form, the opinions of an Educational Sciences expert, a Turkish teacher and an English teacher were consulted. The feedback received from experts was taken into consideration and necessary arrangements were made.

In the study, an observation form was created to determine the situation of the students in the classroom during the applications with the unstructured observation type and to determine how these affect the study. Unstructured observation is a method that provides freedom to the observer in accessing and recording information. It is carried out in natural environments where the behaviors occur and is mostly performed with the participant observation role in which the researcher is in the environment (Büyüköztürk et al., 2016; Yıldırım \& Şimşek, 2013;).

\section{Data Analysis}

The pretest and posttest data collected from the experimental and control groups with the metacognitive awareness inventory and the English self-efficacy belief scale were used for the sub-purposes of the study and dependent and independent groups t-tests were analyzed using the SPSS 20 program. In the analysis with significant difference, eta-square effect size was calculated. This value ranges between 0-1.00. The effect size was defined as small, medium and large, corresponding to the values of .01, .06 and .14, respectively (Büyüköztürk, 2016).

Interview form data obtained in the qualitative dimension of the study were analyzed by content analysis technique. Content analysis; basically, it is the logical arrangement of similar data by reaching certain codes and themes and the interpretation of these data in an understandable way (Yildırım \& Şimşek, 2013). The obtained data were analyzed by coding the data, arranging the codes, identifying and interpreting the findings. Research findings were analyzed based on each question. Themes were found based on the codes that emerged after the coding process was completed (Yıldırım \& Şimşek, 2013). The findings obtained by 
editing the codes are defined and interpreted. Tables were prepared in data presentation and codes were presented together with their frequencies.

The similarity rate between the coders is an indicator of the reliability of the data (Baltac1, 2017). The reliability analysis formula of Miles and Huberman (1994) was used for the reliability analysis of the data obtained through the interview form: Reliability $=$ Number of consensus $\div$ (Agreement + Disagreement $) \mathrm{x}$ 100.The researcher and the expert whose opinion was taken, with 25 codes on the interview data. While providing consensus, they differed in 5 codes. When the obtained code numbers are replaced in the formula; Reliability $=25 \div(25+5) \times 100$. Reliability was calculated as $=.83$. This value showing internal consistency should be at least .80 (Miles \& Huberman, 1994; Patton, 2002). Accordingly, it is seen that the interview data are reliable. Original quotations from students' views were included in order to support the results obtained. Due to the confidentiality principle, the real names of the students participating in the research were not used, the students were coded as SB1, SB2, SB3, ... SG15 and SG1, SG2, SG3, ..... SG15. In the codes, "S" refers to the student; “B" represents male student and "G" represents female student.

\section{Findings}

In this section, findings on the effect of the Universal Design for Learning applied in the eighth grade English course on students' metacognitive awareness and English self-efficacy beliefs, as well as content analysis based on the interview and observation data are included.

\section{Independent Groups T-Test Findings Regarding the Metacognitive Awareness Posttest Scores of the Experimental and Control Groups}

Independent groups t-test findings regarding the metacognitive awareness posttest scores of the experimental and control groups are given in Table 4.

Table 4. Independent Groups T-Test Findings Regarding the Metacognitive Awareness Posttest Scores of the Experimental and Control Groups

\begin{tabular}{lccccccc}
\hline Scale & $\mathbf{n}$ & $\overline{\mathbf{X}}$ & $\mathbf{S}$ & $\mathbf{S d}$ & $\mathbf{t}$ & $\mathbf{p}$ & $\boldsymbol{\eta} 2$ \\
\hline Control & 26 & 113.15 & 31.9 & \multirow{2}{*}{5} & \multirow{2}{*}{12.97} & $.000^{*}$ & .77 \\
Experimental & 26 & 213.92 & 23.43 & & & & \\
\hline${ }^{*} \mathrm{p}<.05$ & & & & & & &
\end{tabular}

As seen in Table 4, according to the independent groups t-test results regarding the metacognitive awareness posttest scores of the experimental and control groups, it was observed that there was a significant difference in English self-efficacy beliefs in favor of the experimental group, $t(50)=7.93, p<.05$. Considering the effect size, it is seen that the variance observed in the metacognitive awareness of the experimental and control group students is $77 \%$ dependent on the group and this effect is at a high level.

\section{Self-Efficacy Beliefs of Experimental and Control Groups in English Posttest Independent Groups T-Test Findings}

Independent groups t-test results regarding the posttest scores of the English self-efficacy beliefs of the experimental and control groups are given in Table 5.

Table 5. Self-Efficacy Beliefs of Experimental and Control Groups in English Posttest Independent Groups T-Test Findings

\begin{tabular}{lccccccc}
\hline Scale & $\mathbf{n}$ & $\overline{\mathbf{X}}$ & $\mathbf{S}$ & $\mathbf{S d}$ & $\mathbf{t}$ & $\mathbf{p}$ & $\eta \mathbf{2}$ \\
\hline Control & 26 & 67.00 & 16.06 & \multirow{2}{*}{50} & 7.93 & $.000^{*}$ & .58 \\
Experimental & 26 & 117.07 & 27.86 & & & & \\
\hline${ }^{*} \mathrm{p}<.05$ & & & & & & &
\end{tabular}


As seen in Table 5, it was observed that there was a significant difference in English self-efficacy beliefs in favor of the experimental group, according to the results of the independent groups test between the English self-efficacy belief posttest scores of the experimental and control groups, $t(50)=7.93, p<.05$. Considering the effect size, it is seen that $58 \%$ of the variance observed in the English self-efficacy beliefs of the experimental and control group students depends on the group and this effect is at a high level.

\section{Dependent Groups T Test Findings Related to the Experimental Group's Self-Efficacy Beliefs in English Pre-test and Post-test Scores}

The dependent Groups T Test Findings Related to the Experimental Group's Self-Efficacy Beliefs in English Pre-test and Post-test Scores are presented in Table 6 below.

Table 6. Dependent Groups T-Test Findings Related to the Experimental Group's Self-Efficacy Beliefs in English Pre-test and Post-test

\begin{tabular}{ccccccc}
\hline Scale & $\mathbf{n}$ & $\overline{\mathbf{X}}$ & $\mathbf{S}$ & $\mathbf{s d}$ & $\mathbf{t}$ & $\mathbf{p}$ \\
\hline Pre-test & 26 & 83.73 & 17.09 & 25 & 6.76 & $.000^{*}$ \\
Post-test & 26 & 117.07 & 27.86 & & & \\
\hline${ }^{*} \mathrm{p}<.05$ & & & &
\end{tabular}

As seen in Table 6, as a result of the curriculum based on Universal Design, a significant increase was observed in the English self-efficacy beliefs of the experimental group students, $t(25)=6.76, p<.05$.

\section{Dependent Groups T-Test Findings Regarding the Experimental Group's Metacognitive Awareness Scores Pretest-Posttest Scores}

The dependent groups t-test results regarding the metacognitive awareness pretest-posttest scores of the experimental group are given in Table 7.

Table 7. Dependent Groups T-Test Findings Related to the Pre-test-Post-test Scores of the Experimental Group's Metacognitive Awareness

\begin{tabular}{ccccccc}
\hline Scale & $\mathbf{n}$ & $\overline{\mathbf{x}}$ & $\mathbf{S}$ & $\mathbf{s d}$ & $\mathbf{t}$ & $\mathbf{p}$ \\
\hline Pre-test & 26 & 131.23 & 27.27 & 25 & 11.9 & $.000^{*}$ \\
Post-test & 26 & 213.92 & 23.43 & & & \\
\hline${ }^{*} \mathrm{p}<.05$ & & & & & &
\end{tabular}

As seen in Table 7, as a result of the curriculum based on Universal Design, there was a significant increase in the experimental group students' metacognitive awareness within the group, $\mathrm{t}(25)=11.9, \mathrm{p}<.05$.

\section{The Relationship Between Universal Design for Learning Secondary School Eighth Grade Students' Metacognitive Awareness Scores and English Self-Efficacy Scores}

Correlation analysis was conducted to determine whether there is a significant relationship between the metacognitive awareness scores of secondary school eighth grade students and their English self-efficacy scores and the findings are given in Table 8.

Table 8. The Relationship Between Secondary School Eighth Grade Students' Metacognitive Awareness Scores and English Self-Efficacy Belief Scores

\begin{tabular}{lccc}
\hline & Variables & $\begin{array}{c}\text { Metacognitive } \\
\text { Awareness }\end{array}$ & $\begin{array}{c}\text { English Self-Efficacy } \\
\text { Belief }\end{array}$ \\
\hline According to Experimental & Metacognitive Awareness & - & $.731^{*}$ \\
\hline
\end{tabular}




\begin{tabular}{|c|c|c|c|}
\hline Group Pretest Results & English Self-Efficacy Belief & & - \\
\hline \multirow{2}{*}{$\begin{array}{l}\text { According to Experimental } \\
\text { Group Posttest Results }\end{array}$} & Metacognitive Awareness & - & $.677^{*}$ \\
\hline & English Self-Efficacy Belief & & - \\
\hline \multirow{2}{*}{$\begin{array}{l}\text { According to the Control } \\
\text { Group Pretest Results }\end{array}$} & Metacognitive Awareness & - & $.438^{*}$ \\
\hline & English Self-Efficacy Belief & & - \\
\hline \multirow{2}{*}{$\begin{array}{l}\text { According to Control } \\
\text { Group Posttest Results }\end{array}$} & Metacognitive Awareness & - & .256 \\
\hline & English Self-Efficacy Belief & & - \\
\hline
\end{tabular}

According to the correlation analysis results in Table 8, there is a high level of positive correlation between metacognitive awareness scores and English self-efficacy scores in the experimental group according to the pre-test and post-test results (Pearson's $\mathrm{r}=.731, \mathrm{p}=<.05$ ), ( Pearson's $\mathrm{r}=.677, \mathrm{p}=<.05$ ), according to the pre-test results of the control group, there is a moderate positive correlation between metacognitive awareness scores and English self-efficacy scores (Pearson's $\mathrm{r}=.438, \mathrm{p}=.05$ ). According to the posttest results of the control group, it is seen that there is a weak positive correlation between metacognitive awareness scores and English self-efficacy scores.

\section{Findings Regarding Secondary School Eighth-Grade Students' Opinions about Universal Design for Learning}

The answers given by the students to the question of whether the teaching based on Universal Design for Learning in English lessons contributes to their learning is given in Table 9.

Table 9. Students' Answers to the Question Regarding whether the Teaching Practices Based on Universal Design for Learning Contribute to Their Learning in English Lessons

\begin{tabular}{lc}
\hline Codes & f \\
\hline Effective Learning & 26 \\
Easy/Permanent Learning & 18 \\
Fun & 14 \\
Visual & 12 \\
Interesting & 8 \\
Active Participation & 5 \\
Reification & 3 \\
\hline
\end{tabular}

As seen in Table 9, all of the students (26/26) thought that their teachers' use of the interactive board in their English lessons, teaching the lesson through slides, presentations and videos, and using posters related to the subjects contributed to their learning and these were beneficial. More than half of the students (18/26) stated that they learned the lessons and subjects permanently thanks to the activities implemented. More than half of the students (14/26) stated that using these tools in the lesson made the lesson more enjoyable. 12 out of 26 students state that the interactive board enabled the visual learning of videos and slides and is thus effective. They stated that they learned by having fun. 8 of the students stated that the lessons became more interesting for them thanks to the tools used. 5 out of 26 students stated that they became more active in the lessons by including interactive boards, videos and slides. 3 out of 26 students stated that the aforementioned tools provided concrete examples in English lessons and thus benefited them to learn. Some of the students' views on this subject are as follows: 
SG1: "Of course yes. It makes lessons more fun. It improves my visual intelligence. In this way, what we learn becomes more permanent. We have the opportunity to listen to the listening activities in the textbooks through the interactive board so that I can hear the words being spoken and my learning becomes more permanent."

SG4: "Yes, I think it contributes because when we teach the lesson with these tools, our lesson is more fun, which makes it easier for me to understand and learn the lesson. In addition, the fact that the subjects are more permanent through slides and videos visually helps me and contribute to my learning. Besides, it enables me to listen to the lesson more carefully and to be more active in the lessons. "

SB8: "Yes, because I think teaching lessons from the interactive board is more fun and efficient. Visual tools such as pictures and photographs make my learning permanent. My desire to listen to the lesson is increasing. Educational games that we play on the interactive board are very useful and fun for the development of my vocabulary. "

The answers given by the students to the question of whether the teaching practices based on Universal Design for Learning applied in English lessons contribute to their interest in the lesson, their active participation in the lesson, and their beliefs that they can succeed, are given in Table 10.

Table 10. Students' Responses Regarding the Effect of Teaching Practices Based on Universal Design on Learning Processes

\begin{tabular}{lc}
\hline Codes & f \\
\hline Useful in Learning & 25 \\
Interest in Lesson & 16 \\
Active Participation & 14 \\
Attention & 12 \\
Belief in Succes & 10 \\
Fun & 7 \\
Increases Self-Confidence & 3 \\
Not Effective İn Learning & 1 \\
\hline
\end{tabular}

As can be seen in Table 10, almost all of the students (25/26) taught with curriculum based on Universal Design for Learning stated that it had a positive effect on their belief that they could succeed in English lessons. 16 out of 26 students stated that their interest in English lessons increased thanks to these tools. More than half of the students (14/26) stated that they participated more actively in the lessons and this also increased their success. A few of the students (7/26) thought that the lessons were more enjoyable thanks to the tools and materials used. Only 1 of 26 students stated that the presence of interactive boards, slides, presentations, videos, posters, and thinking maps in the lessons did not affect the development of their desire to listen to the lesson, their active participation in the lesson and the belief that they could succeed in the English lesson. Some of the students' views on this subject are as follows:

SB4: "I am interested in using tools such as slides, presentations and videos in English lessons, my desire to participate in the lesson became more active and I listen to my lesson more carefully. I can focus more comfortably on the interactive board. With these tools, the more I learned, the more I believed I could achieve this lesson. "

SG14: "Yes, I think it is beneficial because if our teacher had made us the lesson directly from the book, I would not like this lesson that much. The fact that our teacher treated the lesson with visuals, fun slides and videos made us interested in the lesson, our attention and desire to listen increased. From my point of view, I attend classes more than before, and I have increased my belief that I can succeed in English lessons. "

SG12: "Yes, we haven't used the interactive board as much as this year in previous years, which made me dislike English very much. My interest in the course increased thanks to these tools. When we teach the lesson from the interactive board, I can feel myself in the lesson more comfortably, I become more active in the lesson, which comes back 
to me as a success in the exams. Also, as I attend classes, my self-confidence increases and this increases my belief that I can succeed in English lessons.

\section{Findings Regarding the Observation of the Experimental Group Students Regarding the Application of Teaching Based on Universal Design for Learning}

The qualitative findings obtained regarding the observations in the experimental group at the end of the 21-week period are given below:

- It was observed that the interaction of the students with their peers and the teacher was high in the lessons where the teaching method based on Universal Design for Learning was applied.

- It was observed that the students participated in the lesson more effectively and their interest levels were quite high thanks to the various teaching methods and materials used during the lesson.

- During the activities, the teacher was generally in a guiding position and tried to answer the questions of the students.

- It was observed that the students had a lot of fun while doing different activities such as mind maps and puzzle activities, and they were very satisfied with the use of an activity they do in their daily life in their free time.

- There was a significant rise in students' interest in the lesson. It was observed that even the students who were uninterested and less interested in the lessons taught with the normal curriculum actively tried to participate in the lessons in which the teaching based on Universal Design for Learning was applied.

- It was observed that the lessons prepared with the teaching method based on Universal Design for Learning created a more comfortable and enjoyable classroom environment.

\section{Results, Discussion and Suggestions}

In this part of the study in which the effect of Universal Design for Learning on secondary school students' metacognitive awareness and English self-efficacy beliefs was investigated, comments, results and suggestions for these results were presented.

- It was concluded that teaching based on the teaching approach based on universal design provides a positive increase in the metacognitive awareness of students in English lessons.

- It was concluded that teaching based on Universal Design for Learning provides a positive increase in students' self-efficacy beliefs in English lessons.

- According to the pre-test and post-test results of the experimental group, it is seen that there is a high level of positive correlation between the metacognitive awareness scores and the English selfefficacy belief scores, and there is a moderate positive correlation between the metacognitive awareness scores and the English self-efficacy scores according to the pre-test results of the control group. According to the posttest results of the control group, it is seen that there is a weak positive correlation between metacognitive awareness scores and English self-efficacy scores.

- Within the scope of teaching based on Universal Design for Learning, the teacher's use of the interactive board in English lessons, the course being processed through slides, presentations and videos, and the use of posters related to the subjects had a positive effect according to the student views. In this context, teaching based on universal design, according to students' opinions, in the realization of easy and permanent learning; making the classroom environment fun and the lesson interesting; at the point of enabling visual learning; in ensuring the active participation of students in the lessons; in increasing students' beliefs of success; It has a positive effect on the increase of students' self-confidence. 
In this study, it was observed that teaching based on Universal Design for Learning provided a positive increase in the metacognitive awareness of the students in the group in English lessons.

Pressley \& Harris (1990) stated that it is a common problem that students face academic failure and have learning difficulties and that the most important reason of this situation is the lack of knowledge underlying students' inability to use learning strategies effectively. Based on this information, it can be stated that with the effect of teaching based on Universal Design for Learning on the metacognitive awareness of the students, the success of the student in the English course will increase, and thus both his interest in the lesson and his motivation can improve. Similar to the results of this study, Ur Rahman (2010) stated in his study that metacognitive awareness is significantly associated with students' performance. Science students who developed high-level metacognitive awareness performed well in the test. In his study, Strickland (2011) informed both general and special education teachers about how to apply universal design-based teaching in the seventh grade and how to cooperate effectively with each other to ensure access and success for all students. As a result of the research, it was stated that teaching based on Universal Design for Learning was successful. Khonamri (2011), in his study investigating the relationship between metacognitive awareness and comprehension monitoring of English language learners' reading strategies in the context of a foreign language, concluded that reading strategies combine metacognitive awareness and comprehension skills of academic reading texts. In his study, Baş (2012) concluded that teaching learning strategies has a positive effect on students' academic achievement, metacognitive awareness levels and attitudes towards the course.

In this study, it was seen that teaching based on Universal Design for Learning increased students' selfefficacy beliefs positively in English lessons. According to Pintrich and Schunk (1996), the answers sought to the questions about why students choose some tasks and why they stay away from others, why they are successful in some and why they are not in others, strengthens the idea that students' beliefs about themselves are key factors for academic success or failure. In this sense, it is possible to say that self-efficacy is a vital part of motivation and is very effective in the learning process. Therefore, self-efficacy has also come to the fore in language learning research studies. Some of the studies on English self-efficacy have focused on specific language skills such as listening, speaking, writing, or reading (Mills, Pajares \& Herron, 2006; Rahimi \& Abedini, 2009), and in all these studies, self-efficacy is related to students' success in English class. was proven to be. In addition, some studies (Chen, 2007; Duman, 2007; T1lfarlıoğlu \& Cinkara, 2009) showed that students with high self-efficacy are more successful in English lessons. Based on this, we can state that as a result of teaching based on Universal Design for Learning, students whose self-efficacy in English increased, their belief in themselves and success increases. In a similar study, Mathews (2016) found that teaching based on Universal Design for Learning has positive effects on student achievement, lesson focus and perception.

As a result of the research, it was seen that there is a positive and significant relationship between students' metacognitive awareness and self-efficacy beliefs. It can be said that the student, whose metacognitive awareness has developed, recognizes himself and his working methods, and as a result, gains the feeling of achievement causes the self-efficacy belief to increase with the increase in his belief in himself and success. There have been various studies supporting this result of the study and reporting a positive and significant relationship between metacognitive and self-efficacy beliefs (Nosratinia, Saveiy \& Zaker, 2014; Rahimi \& Abedi, 2014; Yailagh, Birgani, Boostani Hajiyakhchali, 2013; Cera \&, Mancini \& Antoniett, 2013). When the studies conducted are examined, it was observed that metacognitive awareness and self-efficacy belief are often given together and are closely related. Similarly, Yavuz (2009) found a moderate relationship between pre-service teachers 'general self-efficacy levels and general metacognitive awareness in a study in which pre-service teachers' perceptions of self-efficacy and metacognitive awareness of the teaching profession were examined in terms of various variables. Also, Goudarzi, Ghonsooly and Pishghadam (2014) showed that metacognitive awareness was statistically correlated with English self-efficacy and foreign 
language test performance. In Nosratinia et al. (2014), in his study, he showed that there are significant relationships between self-efficacy and metacognitive awareness, self-efficacy and the use of language learning strategies of students learning English as a foreign language, and the use of metacognitive awareness and language learning strategies.

All of the experimental group students interviewed stated that teaching based on universal design was an effective method in increasing their metacognitive awareness and self-efficacy beliefs in English. Among the students, the prevailing opinion is that the lessons taught with the teaching method based on universal design are beneficial, keep their interest at a high level, provide active participation, raise their attention, and positively affect their belief in success and their self-confidence. They stated that it is beneficial for the teacher to talk about my studying techniques, that it contributes to how they can work efficiently, increases their success, increases their motivation, provides self-confidence, reduces stress and contributes to their personal development. Mcguire et al. (2006), Spooner (2007), Kortering et al. (2008), Strickland (2011), Katz (2013), Johnson-Harris (2014), Gawronski (2014) defined teaching based on universal design as the teaching method of the future in their studies, and with this teaching method, a teaching that appeals to all students despite individual differences. They emphasized that it is a method. In addition, studies have indicated that teaching based on universal design has positive effects on students' attitudes towards the course, self-efficacy beliefs and motivation, and the results obtained support this study.

Based on this information, we can say that teaching based on universal design takes into account the individual differences of the student, and includes elements that support not only academic success but also engagement to the lesson, active participation, motivation, self-efficacy belief and metacognitive awareness. In addition, in the observations made to the experimental group, it was revealed that the students actively participated in the lessons prepared according to the teaching based on universal design and interacted with their friends and teachers. It can be stated that this situation positively affects students' interest in the course and thus their success.

Suggestions made in line with the results of the study are presented below:

- It was observed that the curriculum prepared with a teaching approach based on universal design is more effective in English lessons. For this reason, it is thought that the inclusion of Universal Design for Learning in the curricula of other courses may be effective in increasing the success of students in these courses.

- The program, which was prepared according to the teaching approach based on Universal Design for Learning, is planned in six units. As can be seen in the findings, it is thought that it would be beneficial to not limit the program studies prepared with this effective approach to certain units and to use them in other units during the year. 


\section{REFERENCES}

Abacı, R., Akın, A., \& Çetin, B. (2007). Bilişötesi farkındalık envanterinin Türkçe formunun geçerlik ve güvenirlik çalışması. Kuram ve Uygulamada Ĕ̆itim Bilimleri Dergisi, 7(2), 7-32.

Abell, M., Jung, E., \& Taylor, M. (2011). Students' perceptions of classroom instructional environments in the context of 'Universal Design for Learning'. Learning Environment Research, 14(2), 171-185.

Altındağ, M., \& Senemoğlu, N. (2013). Metacognitive skills scale, H. U. Journal of Education, 28(1), 15-26.

Artelt, C., \& Schneider, W. (2015). Cross-country generalizability of the role of metacognitive knowledge in students' strategy use and Reading competence. Teachers College Record, 117(1). 1-32.

Bandura, A. (1982). Self-efficacy mechanism in human agency, American Psychologist, 32(2),122-147.

Bandura, A. (1994). Self-efficacy, Encyclopedia of Human Behavior, 4, 71-81.

Bandura, A. (1997). Self-efficacy: the exercise of control. W.H. Freeman and Company, New York, U.S.A.

Baş, G. (2012). Öğrenme stratejileri öğretiminin öğrencilerin İngilizce dersindeki akademik başarılarına, tutumlarına ve bilişötesi farkındalık düzeylerine etkisi. Kuramsal Ĕ̆itimbilim Dergisi, 5(1), 49-71.

Brown, A. L. (1987). Metacognition, executive control, self-regulation, and other more mysterious mechanisms. In F. E. Weinert \& R. H. Kluwe Eds., Metacognition, motivation, and understanding pp. 65116. Hillsdale, NJ: Lawrence Erlbaum.

Baltacı, A. (2017). Nitel veri analizinde Miles-Huberman modeli. Ahi Evran Üniversitesi Sosyal Bilimler Enstitüsü Dergisi (AEÜSBED), 3(1), 1-15.

Büyüköztürk, Ş. (2016). Deneysel desenler. Ankara: Pegem Akademi.

Büyüköztürk, Ş., Kılıç-Çakmak, E., Akgün, Ö. E., Karadeniz, Ş., \& Demirel, F. (2016). Bilimsel araştırma yöntemleri. Ankara: Pegem Akademi.

CAST. (2017). Retrieved from CAST Website. Center for Universal Design. 2008. About UD. Raleigh: North Carolina State University. Retrieved from http://www.ncsu.edu/ncsu/design/cud/about_ud/ about_ud.htm 21.08.2017.

Cera, R., Mancini, M., \& Antonietti, A. (2013). Relationships between metacognition, self-efficacy and selfregulation in learning. ECPS Journal, 7, 115-141.

Chen, H.Y. (2007). Learning to learn: The impact of strategy training. ELT Journal, 61(1), 20-29.

Creswell, J. W., Plano Clark, V. L., Gutmann, M. L., \& Hanson, W. E. (2003). Advanced mixed methods research design. Abbas Tashakkori and Charles Teddlie (Ed.), Hand Book of Mixed Methods: In Social and Behavioral Research. California: SAGE Publications Inc.

Duman, B., (2007). Lise öğrencilerinin ingilizceye yönelik öz yeterlik algı puanlarının cinsiyete, alanlara ve farklı düzeylere göre ingilizce başarısını yordama gücü.Yüksek Lisans Tezi. Yıldız Teknik Üniversitesi Eğitim Bilimleri Enstitüsü, İstanbul.

Edyburn, D. L. (2010). Would you recognize universal design for learning if you saw it? Ten propositions for new directions for the second decade of UDL, Learning Disability Quarterly, 331, 33-41.

Ekici, G. (2012). Akademik öz yeterlilik ölçeği: türkçeye uyarlama, geçerlik ve güvenirlik çalışması, Hacettepe Üniversitesi Ĕ̆itim Fakültesi Dergisi, 43, 174-185.

Flavell, J. H. (1979). Metacognition and cognitive monitoring: A new area of cognitive developmental inquiry. American Psychologist, 34, 906-911.

Garner, R., \& Alexander, P. A. (1989). Metacognition: Answered and unanswered questions. Educational Psychologists. 24,143-158. 
Gawronski, M. E. (2014). Universal design for learning: perceptions of faculty and students at a northeastern communty college. Phd Thesis. Colorado State University.

Goudarzi, E., Ghonsooly, B., \& Pishghadam, R. (2014). An exploration of the interrelationships among EFL learners' English self-efficacy, metacognitive awareness, and their test performance: A structural equation modeling approach, 22, 325-339.

Hancı Yanar, B., \& Bümen, N. (2012). İngilizce ile ilgili öz yeterlik inancı ölçeğinin geliştirilmesi. Kastamonu Ĕ̆gitim Dergisi, 20(1), 97-110.

Izzo, M., Murray, A., \& Novak, J. (2008). The faculty perspective on universal design for learning. Journal of Postsecondary Education and Disability, 212, 60-72.

Johnson-Harris, K. M. (2014). The effects of universal design for learning on the academic engagement of middle school students. Phd Thesis, Southern Illinois University, Carbondale.

Kabadayı, A. (2003). Öğrenci-merkezli yabancı dil öğretim modeli tercih ölçeği. Dokuz Eylül Üniversitesi Sosyal Bilimler Enstitüsü Dergisi, 5(1), 56.

Kannan, R. (2009). Difficulties in learning English as a second language, ESP World, 8,1-4.

Karasar, N. (2016). Bilimsel araştırma yöntemi. Ankara: Nobel Yayın Dağıtım.

Katz, J. (2013). The Three-Block model of universal design for learning (UDL): Engaging students in inclusive education. Canadian Journal of Education, 368(1), 153-194.

Keskin, G. Ü., \& Orgun, F. (2006). Öğrencilerin öz etkililik ve yeterlilik düzeyleri ile başa çıkma stratejilerinin incelenmesi, Anatolian Journal of Psychiatry, 7, 92-99.

Khonamri, F., \& Elahe, M. K. (2011). Metacognitive awareness and comprehension monitoring in reading ability of Iranian EFL learners. Profile, 13(2), 99-111.

King-Sears, M. (2009). Universal Design for Learning: Technology and Pedagogy. Learning Disability Quarterly. 32. 199-201. 10.2307/27740372.

Kortering, L. J., Terry W., Mclannon, P., \& Braziel, M. (2008). Universal design for learning: A look at what algebra and biology students with and without high incidence conditions are saying. Remedial and Special Education, 296, 352-363.

Long, R. B. (1969). Linguistic universals, deep structure, and English as a second language. TESOL Quarterly, 3, 123-132.

Luszczynska, A., Gutierrez- Dona, B., \& Schwarzer, R. (2005), General self -efficacy in various domains of human functioning: evidence from five countries, International Journal of Psychology, 40(2), 80-89.

Mathews K. M. (2016). Transformative models in K-12 education: The impact of a blended universal design for learning intervention an experimental mixed methods study. University of San Diego.

Mcguire, J. M., Scott, S. S., \& Shaw, S. F. (2006). Universal design and its applications in educational environments. Remedial and special education, 273, 166-175.

Meyer, A., \& Rose, D. H. (2000). Universal design for individual differences. Educational Leadership, 58(3), 3943.

Miles, M, B., \& Huberman, A. M. (1994). Qualitative data analysis: An expanded sourcebook. (2nd Ed.), Thousand Oaks, CA: Sage.

Mills, N., Pajares, F., \& Herron, C. (2006). A revolution of the role of anxiety: self-efficacy, anxiety, and their relation to reading and listening proficiency. Foreign Language Annals, 39(2), 276-294. 
Molenberghs, P., Trautwein, F. M., Böckler, A., Singer, T., \& Kanske, P. (2016). Neural correlates of metacognitive ability and of feeling confident: a large-scale fMRI study. Social Cognitive $\mathcal{E}$ Affective Neuroscience, 11(12), 1942-1951. https://doi.org/10.1093/scan/nsw093.

Nosratinia, M., Saveiy, M., \& Zaker, A. (2014). EFL learners' self-efficacy, metacognitive awareness, and use of language learning strategies: How are they associated. Theory and Practice in Language Studies, 4(5), 1080-1092.

Nunn, R., (2011). Improving method-in-use through classroom observation. IRAL, 49, 55-70.

Pajares, F., \& Urdan, T. (2002). Self-efficacy beliefs of adolescents. USA: Age Publishing.

Paris, S. G., \& Winograd, P. (1990). How metacognition can promote academic learning and instruction. In B. F. Jones \& L. Idol Eds., Dimensions of thinking and cognitive instruction pp. 15-51. Hillsdale, NJ: Lawrence Erlbaum.

Patton, M. Q. (2002). Qualitative research and evaluation methods (3rd Ed.). London: Sage Publications, Inc.

Pintrich, P., \& Schunk, D. (1996). Motivation in education: Theory, research E applications. Englewood Cliffs, NJ: Prentice-Hall.

Pressley, M., \& Ghatala, E. S. (1990). Self-regulated learning: Monitoring learning from text. Educational Psychologists. 25.19-33.

Pressley, M., \& Harris, K. R. (1990). What we really know about strategy instruction. Educational Leadership, $48(1), 31-34$.

Rahimi, A., \& Abedini, A. (2009). The interface between EFL learners' self-efficacy concerning listening comprehension and listening proficiency. Novitas Royal,3(1), 14-28.

Rose, D. H., \& Meyer, A. (2002). Teaching Every Student in the Digital Age. Alexandria,VA: Association for Supervision and Curriculum Development.

Rowe, H. (1988). Metacognitive skills: Promises and problems. Australian Joumal of Reading. 114, $227-237$.

Sáiz, M. M. C., \& Carbonero, M. M. Á. (2017). Metacognitive precursors: An analysis in children with different disabilities, Brain Sciences, 7(10), 1-14. https://doi.org/10.3390/brainsci7100136.

Schelly, C. L., Davies, P. L. \& Spooner, C. L. (2011). Student perceptions of faculty implementation of universal design for learning. Journal of Postsecondary Education and Disability, 24(1), 17-30.

Schraw, G. (1998). Promoting general metacognitive awareness. Instructional Sciences, 26, $113-125$. https://doi.org/10.1023/A:1003044231033

Schraw, G., \& Dennison, R. S. (1994). Assessing metacognitive awareness. Contemporary Educational Psychology, 19, 460-475. doi:10.1006/ceps.

Sonowal, M., \& Kalita, M. (2017) A study on metacognitive awareness and academic achievement of higher secondary level students of Dibrugarh town of Assam, India. The Clarion: International Multidisciplinary Journal, 6(1), 69-74. https://doi.org/10.5958/2277-937X.2017.00012.0

Spooner, F., Baker, J. N., Harris, A. A., Delzell, L. A., \& Browder, D. M. (2007). Effects of training in universal design for learning on lesson plan development. Remedial and Special Education, 28(2), 108-116.

Strickland, A. (2011). Universal design for learning: access to the general curriculum for students with severe cognitive disabilities. (Master's Thesis, East Carolina University). Retrieved from the Scholarship. (http://hdl.handle.net/10342/3571.)

Sunel, A. H. (1989). Yabancı dil öğretiminde metot sorunu. Hacettepe Üniversitesi Ĕ̆itim Fakültesi Dergisi, 4, 140. 
Tilfarlıoğlu, F. T., \& Cinkara, E. (2009). Self-efficacy in EFL: differences among proficiency groups and relationship with success. Novitas Royal, 3(2), 129-142.

Tunca, N., \& Alkın-Şahin, S. (2014). Öğretmen adaylarının bilişötesi (üstbiliş) öğrenme stratejileri ile akademik özyeterlik inançları arasındaki ilişki. Anadolu Journal of Educational Sciences International, 4(1), 47-56. https://doi.org/10.18039/ajesi.89592

UDLcenter. (2017). http://www.udlcenter.org/aboutudl, Retrieve Date: 21.08.2017.

Ur Rahman, F., Jumani, N. B., Chaudry, M. A., Chisti, S. U. H., \& Abbasi, F. (2010). Impact of metacognitive awareness on performance of students in chemistry. Contemporary Issues in Education Research, 3(10), 3944.

Wilson, J. (1999). Defining metacognition: A step towards recognizing metacognition as a worthwhile part of the curriculum. Paper presented at the Australian Association for Research in Education Conference, Melbourne.

Yailagh, M. S., Birgani, S. A., Boostani, F., \& Hajiyakhchali, A. (2013). The relationship of self-efficacy andachievement goals with metacognition in female high school students in Iran. Procedia - Social and Behavioral Sciences 84, 117 - 119.

Yavuz, D. (2009). Öğretmen adaylarının öz yeterlik algıları ve üstbilişsel farkındalıklarının çeşitli değişkenler açısından incelenmesi. Yüksek Lisans Tezi. Zonguldak: Karaelmas Üniversitesi Sosyal Bilimler Enstitüsü.

Yildirim, A., \& Şimşek, H. (2013). Sosyal bilimlerde nitel araştırma yöntemleri. (9. Bask1). Ankara: Seçkin Yayıncilık.

Yıldız, H., \& Akdağ, M. (2017). The effect of metacognitive strategies on prospective teachers' metacognitive awareness and self-efficacy belief, Journal of Education and Training Studies, 5(12), 30-40. https://doi.org/10.11114/jets.v5i12.2662

Zhao, L., \& Mo, S. (2016). The impact of metacognitive awareness on class performance in financial accoutning courses. Academy of Educational Leadership Journal,20(2), 78-88.

Zimmerman, B. J. (2000). Self-efficacy: An essential motive to learn. Contemporary Educational Psychology, 25(1), 82-91. 